\title{
Fuzzy cognitive modeling of heterogeneous electromechanical systems
}

\author{
V. Borisov', S. Kurilin', N. Prokimnov ${ }^{2}$, M. Chernovalova ${ }^{3 *}$ \\ 1 Branch of the National Research University "MPEI" in Smolensk, Smolensk, Russia \\ ${ }^{2}$ Synergy University, Moscow, Russia \\ ${ }^{3}$ National Research University "MPEI", Moscow, Russia \\ *0208margarita@bk.ru
}

\begin{abstract}
The article presents a method of fuzzy cognitive modeling for heterogeneous electromechanical systems (HEMSs) in the management of innovative design solutions. During the operation of the HEMSs, as a result of their operational aging, the properties of the windings parametric matrices and the HEMSs vector space properties change. Periodic testing of the HEMSs vector space allows obtaining reliable information about the current technical condition of the HEMSs, about its changes during operation and about the risks of operating capability loss. At the same time (I) the presence of proportional changes in signals during sequential testing indicates the homogeneous operational aging of the HEMSs and its rate; (II) a disproportionate change in one of the signals indicates the damage or the development of a heterogeneous aging process; (III) a change in signals with a change in the angular position of the rotor indicates worn bearings or damage of the HEMSs rotor. The article presents the HEMSs model, describes the method for the topological research of the vector space and the method for forming the diagnostic matrices. The deviations of their elements are fuzzy due to the uncertainty of the load, influencing environmental factors and unstable supply voltages. Therefore, for predictive estimation of the HEMSs state, it is proposed to use fuzzy relational cognitive models that allow implementing a completely fuzzy approach to modeling problem situations in these systems. The presented data confirm the growth of the HEMSs heterogeneity under conditions of uncertainty of external influences. The proposed method for predictive estimation of the HEMSs state, based on fuzzy relational cognitive models, provides resistance to an increase in the uncertainty of the estimation results for various models of system dynamics due to a reasonable set of fuzzy vector-matrix operations.
\end{abstract}

Keywords: fuzzy relational cognitive models, predictive estimation, dynamics modeling, vector space, heterogeneous electromechanical systems, fuzzy vector-matrix equations, uncertainty

For citation: Borisov V., Kurilin S., Prokimnov N., Chernovalova M. Fuzzy cognitive modeling of heterogeneous electromechanical systems. Prikladnaya informatika=Journal of Applied Informatics, 2021, vol.16, no.1, pp.3239. DOI: 10.37791/2687-0649-2021-16-1-32-39 


\title{
Нечеткое когнитивное моделирование неоднородных электромеханических систем
}

\author{
В. В. Борисов ${ }^{1}$, С. П. Курилин', Н. Н. Прокимнов ${ }^{2}$, М. В. Черновалова $3^{3 *}$ \\ 1 Филиал ФГБОУ ВО «НИУ "МЭИ"» в г. Смоленске, Смоленск, Россия \\ 2 университет «Синергия», Москва, Россия \\ ${ }^{3}$ ФГБОУ ВО «НИУ "МЭИ"», Москва, Россия \\ *0208margarita@bk.ru
}

\begin{abstract}
Аннотация. Статья представляет метод нечеткого когнитивного моделирования неоднородных электромеханических систем (НЭМС) при управлении инновационными проектными решениями. В ходе эксплуатации НЭМС в результате их эксплуатационного старения изменяются свойства параметрических матриц обмоток и свойства векторного пространства НЭМС. Периодическое тестирование векторного пространства НЭМС позволяет получить достоверные сведения о текущем техническом состоянии НЭМС, о его изменениях в ходе эксплуатации и о рисках потери работоспособности. При этом (I) наличие пропорциональных изменений сигналов при последовательном тестировании свидетельствует об однородном эксплуатационном старении НЭМС и о его темпах; (II) непропорциональное изменение одного из сигналов говорит о повреждении или о развитии процесса неоднородного старения; (III) изменение сигналов при изменении углового положения ротора указывает на изношенность подшипников или на повреждения ротора НЭМС. В статье представлена модель НЭМС, описаны метод топологического исследования векторного пространства и способ формирования диагностических матриц. Отклонения их элементов носят нечеткий характер из-за неопределенности нагрузки, воздействующих факторов внешней среды и нестабильных питающих напряжений. Поэтому для прогнозного оценивания состояния НЭМС предложено использовать нечеткие реляционные когнитивные модели, которые позволяют реализовать полностью нечеткий подход к моделированию проблемных ситуаций в этих системах. Представленные данные подтверждают нарастание неоднородности НЭМС в условиях неопределенности внешних воздействий. Предлагаемый метод прогнозного оценивания состояния НЭМС, основанный на нечетких реляционных когнитивных моделях, обеспечивает устойчивость к возрастанию неопределенности результатов оценки для различных моделей системной динамики за счет обоснованного набора нечетких векторно-матричных операций.
\end{abstract}

Ключевые слова: нечеткие реляционные когнитивные модели, прогнозное оценивание, моделирование динамики, векторное пространство, неоднородные электромеханические системы, нечеткие векторноматричные уравнения, неопределенность

Для цитирования: Борисов В. В., Курилин С. П., Прокимнов Н. Н., Черновалова М. В. Fuzzy cognitive modeling of heterogeneous electromechanical systems // Прикладная информатика. 2021. Т. 16. № 1. С. 3239. DOI: 10.37791/2687-0649-2021-16-1-32-39

\section{Introduction}

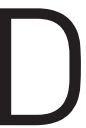
uring the operation of the heterogeneous electromechanical systems (HEMSs), as a result of their wear and possible damage, the properties of the parametric winding matrices and, as a result, the properties of the HEMSs vector space change. Periodic testing of the HEMSs vector space allows obtaining reliable information about the current technical state of the HEMSs, about its changes during operation and about the 